\title{
FORMULATION AND STATISTICAL OPTIMIZATION OF BILAYER SUBLINGUAL TABLETS OF LEVOCETIRIZINE HYDROCHLORIDE AND AMBROXOL HYDROCHLORIDE
}

\author{
PRIYANKA CHOUDHURY*, PULAK DEB, SUVAKANTA DASH
}

Department of Pharmaceutics, Girijananda Chowdhury Institute of Pharmaceutical Science, Azara, Assam, India. Email: priyankachoudhury1812@gmail.com

Received: 08 June 2016, Revised and Accepted: 15 June 2016

\section{ABSTRACT}

Objective: The aim of the present study is to formulate and optimize bilayer sublingual tablets of Levocetrizine hydrochloride and Ambroxol hydrochloride using a $2^{3}$ response surface methodology employing design expert-10.0. Sodium starch glycolate and Camphor were selected as independent variables while disintegration time (sec) and water absorption ratio (\%) were considered as responses.

Methods: The bilayer sublingual tablets were prepared by direct compression and evaluated for various evaluation parameters including hardness, thickness, friability, drug content uniformity, wetting time, water absorption ratio and disintegration time. The prepared optimized bilayer sublingual tablets of Levocetrizine hydrochloride and Ambroxol hydrochloride having above 2 responses-disintegration time (sec) and water absorption ratio.

Results: The optimized batch having concentration of sodium starch glycolate and camphor was found within the standard limit of parametersdisintegration time (sec) and water absorption ratio (\%) as $61 \mathrm{sec}$ and $69.67 \%$.

Conclusion: The direct compression method in this study is relatively simple and safe and a stable, effective and pleasant tasting bilayer sublingual tablet, which has a good balance over disintegration time and water absorption ratio, was formulated.

Keywords: Levocetirizine hydrochloride, Ambroxol hydrochloride, Croscarmellose sodium, Sodium starch glycolate, Camphor, Statistical optimization. (C) 2016 The Authors. Published by Innovare Academic Sciences Pvt Ltd. This is an open access article under the CC BY license (http://creativecommons. org/licenses/by/4. 0/) DOI: http://dx.doi.org/10.22159/ajpcr.2016.v9i5.13343

\section{INTRODUCTION}

The concept of bilayer has been introduced to attain sustain release of drug which refers to tablet containing subunits that either may be same (homogeneous) or different (heterogeneous). Bilayer tablet allows for designing and modulating the dissolution and release characteristics. Bilayer tablet is prepared for one layer for immediate release while the second layer is designed to release drug, later as second dose or in an extended release pattern. Bilayer tablet is suitable for sequential release of two drugs in combination, separate two incompatible substances. Bilayer tablet is preferred when the release profiles of the drugs are different from each other [1]. Levocetirizine, the active isomer of its parent compound, cetirizine, is one of the newest secondgeneration antihistamines. After only 1 dose, it has been found to suppress the cutaneous allergic response to a significantly greater extent than similar drugs in its class. In addition, levocetirizine is effective in the treatment of nasal congestion. Levocetirizine hydrochloride, have low oral bioavailability due to high first-pass metabolism. To minimize such problems levocetirizine hydrochloride is formulated in the form of fast dissolving tablets where the drug is rapidly disintegrated in mouth within fraction of seconds and improves the oral drug bioavailability [2]. Furthermore, ambroxol hydrochloride is a potent mucolytic and mucokinetic, capable of inducing bronchial secretion. It depolymerises mucopolysaccharides directly as well as by liberating lysosomal enzymes network of fibers in tenacious sputum is broken. It is used as expectorant and variety of respiratory disorders including asthma, bronchitis and used in the treatment of a cough. It is particularly useful if mucus plugs are present. In pediatrics, the most common triggers are viral illnesses such as those that cause the common cold. Due to sore throat conditions, the pediatrics patient experiences difficulty in swallowing a tablet type of dosage form. Liquid dosage forms are having their own limitation from stability and dose measurement perspectives. Thus, fast disintegrating tablets would serve as an ideal dosage form for pediatric patients [3]. Optimization with factorial designs is a powerful, efficient and systemic tool that shortens the time required for the development of pharmaceutical dosage forms and improves research and development work. The response surface method has been applied to dosage form design for various kinds of drugs by many researchers.

The computer software have been used almost at every step during the entire optimization cycle ranging from selection of design, screening of factors, use of response surface designs, generation of the design matrix, plotting of three-dimensional (3D)-response surfaces and two-dimensional (2D) contour plots, application of optimum search methods, interpretation of the results, and finally the validation of the methodology [4]. Verily, many software packages lead the user through the data analysis even without a mathematical model or statistical equations in sight. Use of pertinent software can make the design expert optimization task a lot easier, faster, more elegant and economical. Specifically, the erstwhile impossible task of generating varied kinds of 3D-response surfaces manually is accomplished with phenomenal ease using appropriate software (Bolton, 1987; Potter, 1994).Various types of computer softwares are used like-design expert MINITAB, JMP, CARD, MATREX, Cornerstone ${ }^{\mathrm{TM}}$, ECHIP, GRG2, DoE PC IV, STATISTICA etc., [5].

Bilayer sublingual tablets of levocetirizine hydrochloride and ambroxol hydrochloride were prepared using direct compression has been optimized successfully using a face-centered central composite design. It is very efficient and flexible, providing much information on experiment variable effects and overall percentage error in a minimal number of experimental runs. Based on the principles of design of experiments, the methodology involves the use of various types of experimental designs, generation of polynomial mathematical relationships and mapping of the response over the experimental domain to select the optimum formulation. Therefore, the face-centered central composite design was found to be a very suitable tool for process optimization of bilayer sublingual tablets in this study [6]. 


\section{METHODS}

\section{Materials}

Levocetirizine hydrochloride and ambroxol hydrochloride was received as the gift sample from Balaji Drugs, Mumbai, India, Croscarmellose sodium was received from Himedia, Mumbai and sodium starch glycolate (SSG), microcrystalline cellulose, and camphor were received from Merck specialist Pvt. Ltd, Mumbai. All other chemical and reagent used in this study were of analytical grade.

\section{Methods}

Drug-excipients compatibility studies using Fourier transform infrared (FTIR)

The FTIR studies were performed to study drug-excipients interaction in the range 4000-400/cm using an FTIR spectrometer (Bruker Model no - 10059736) and data had been collected [6].

Drug-excipients compatibility studies using differential scanning calorimetry (DSC)

In drug formulation, it is essential to evaluate the possible interactions between the active principle and the superdisintegrants. Levocetirizine hydrochloride and ambroxol hydrochloride powder were mixed with different excipients in the ratio of 1:1 and the resulting physical mixture was examined on DSC (Perkin Elmer 2000). Mixtures have been examined under Nitrogen to eliminate oxidative and pyrolytic effect at a standard heating rate $(2,5$ or $100 \mathrm{C} /$ minute). Thermo gram of pure drug was used as a reference [7].

Formulation of bilayer sublingual tablets of levocetirizine hydrochloride and ambroxol hydrochloride

Preparation of optimized levocetirizine hydrochloride layer

Levocetirizine hydrochloride layer was formulated by using the ingredients SSG and croscarmillose sodium. All the ingredients with drug except magnesium stearate were taken in the mortar. The powder blend was mixed well by using mortar and pestle for 15-30 minutes, and then mixture was passed through \#80 sieves. Finally, magnesium stearate was added as lubricant and mixed thoroughly. The powder blend was compressed using 16 stations tablet compression machine (Shakti Pharmatech, Ahmedabad, India) to produce tablets of levocetirizine hydrochloride weighing $120 \mathrm{mg}$ having diameter of $6 \mathrm{~mm}[8]$.

The materials required for preparation of Optimised Levocetrizine layer was given in the Table1.

The materials required for preparation of optimised Ambroxol hydrochloride was given in Table 2.

\section{Preparation of optimized ambroxol hydrochloride layer}

Ambroxol hydrochloride layer was formulated using the ingredients SSG and camphor. All the ingredients with drug except magnesium stearate were taken in the V-blender. The powder blend was mixed well at $20 \mathrm{rpm}$ for 15 minutes, and then mixture was passed through

Table 1: Materials used for preparation of optimized levocetirizine hydrochloride layer

\begin{tabular}{lll}
\hline S. no & Ingredients & Amounts (mg) \\
\hline 1 & Levocetirizine hydrochloride & 5 \\
2 & Croscarmellose sodium & 16 \\
3 & SSG & 10 \\
4 & Microcrystalline cellulose & 63 \\
5 & Sodium saccharine & 4 \\
6 & Talc & 1 \\
7 & Magnesium stearate & 1 \\
8 & Mannitol & 20 \\
\hline SSG: Sodium &
\end{tabular}

SSG: Sodium starch glycolate
\#40 sieves. Finally, magnesium stearate was added as lubricant and mixed thoroughly. The powder blend was compressed using 8 stations tablet compression machine (Shakti Pharmatech, Ahmadabad, India) to produce tablets of ambroxol hydrochloride weighing $60 \mathrm{mg}$ having diameter of $6 \mathrm{~mm}[6]$.

Formulation of bilayer sublingual tablets of levocetirizine hydrochloride and ambroxol hydrochloride

The bilayer sublingual tablets of levocetirizine hydrochloride and ambroxol hydrochloride were prepared using two layers as discussed above. The optimized levocetirizine hydrochloride layer and ambroxol hydrochloride were compressed using double-sided tablet press [6,7].

Evaluation studies of optimized fast dissolving tablets of ambroxol hydrochloride

Pre-compression parameter

Before compression, powder was evaluated for flow and compressibility parameters. Flow properties of powder were determined by angle of repose method. Compressibility index of powder was determined by Carr's index and Hausner's ratio.

\section{Bulk density and tapped density}

Tapped density is the total mass of the powder to the tapped volume of the powder. It is expressed in $\mathrm{g} / \mathrm{ml}$. It is expressed in $\mathrm{g} / \mathrm{ml}$.

Bulk density, $\mathrm{D}=\mathrm{M} / \mathrm{V}_{\mathrm{b}}$

Where M - Mass of the powder

$\mathrm{V}_{\mathrm{b}}$. Bulk volume of the powder.

Tapped density, $\mathrm{Dt}=\mathrm{M} / \mathrm{Vt}$

Where M - Mass of the powder

$\mathrm{Vt}$ - Tapped volume of the powder [8].

\section{Compressibility index (I) and Hausner's ratio}

Carr's index and Hausner ratio measure the propensity of the powder to be compressed and the flow of granules [6]. It is given by formula:

Carr's index, $\mathrm{I}=(\mathrm{Dt}-\mathrm{Db} / \mathrm{Dt}) \times 100$

Hausner's ratio $=$ Tapped density $/$ bulk density

Angle of repose $(\theta)$

This is the maximum angle between the surface of the pile of a powder and the horizontal plane. Sufficient quantities of granules were passed through a funnel from a particular height onto a flat surface until it formed a heap, which touched the tipped of the funnel. The height of the radius of the heap was measured [6,7]. The angle of repose was calculated as:

Angle of repose, $\tan \theta=h / r$

Where h-height of the pile R-radius of the pile.

\section{Post-compression parameter \\ Hardness}

The test was done as per the standard methods. The hardness of three randomly selected tablets from each formulation was determined by placing each tablet diagonally between the two plungers of tablet hardness tester (with the nozzle) and applying pressure until the tablet broke down into two parts completely and the reading on the scale was noted down in $\mathrm{kg} / \mathrm{cm}^{2}$ [7]. 


\section{Thickness}

The thickness of three randomly selected tablets from each formulation was determined in mm using a vernier caliper (Pico India). The average values were calculated.

\section{Uniformity of weight}

Weight variation test was done as per standard procedure. 20 tablets from each formulation were weighed using an electronic balance, and the average weight was calculated.

\section{Friability}

The friability of tablets was measured using six tablets using a Roche friabilator. Tablets were rotated at $25 \mathrm{rpm}$ for 4 minutes or up to 100 revolutions. The tablets were taken out, dedusted, and reweighed. The percentage friability was calculated from the loss in weight as given in equation below $[7,8]$. The weight loss should not more than $1 \%$.

Friability $(\%)=([$ Initial weight - final weight $] /$ initial weight $) \times 100$.

\section{Drug content}

10 tablets were powdered and the powder equivalent to $15 \mathrm{mg}$ was dispersed in phosphate buffer $\mathrm{pH}$ 6.8. The volume of the solution made up to $10 \mathrm{~mL}$ by media. The mixture was filtered and $1 \mathrm{ml}$ of the filtrate was diluted to $10 \mathrm{~mL}$ using phosphate buffer $\mathrm{pH}$ 6.8. The absorbance of the sample preparations was measured at $243.0 \mathrm{~nm}$ for Ambroxol hydrochloride $[8,9]$.

\section{Wetting time}

A piece of tissue paper folded twice was placed in a small Petri dish containing $6 \mathrm{ml}$ of phosphate buffer $\mathrm{pH}$ 6.8. A tablet was put on the paper, and the time for complete wetting was measured. Three trials for each batch and the standard deviation were also determined [9].

\section{Water absorption ratio}

A piece of tissue paper folded twice was placed in a small Petri dish containing $6 \mathrm{~mL}$ of water. A tablet was put on the tissue paper and allowed to wet completely. The wet tablet was then weighed.

Water absorption ratio $(\mathrm{R})=100(\mathrm{Wa}-\mathrm{Wb}) / \mathrm{Wb}$
Where $\mathrm{Wb}$ and $\mathrm{Wa}$ are the weights of tablet before and after water absorption, respectively.

\section{In-vitro disintegration time}

Disintegration time for sublingual tablets was determined using USP tablet disintegration apparatus with phosphate buffer of $\mathrm{pH} 6.8$ as medium. The volume of medium was $900 \mathrm{~mL}$ and temperature was $37 \pm 0.5^{\circ} \mathrm{C}$. The time in seconds taken for complete disintegration of the tablets with no palatable mass remaining in the apparatus was measured [9].

\section{Optimization data analysis and numerical optimization}

Various response surface methodological techniques in computations for the current optimization study were performed employing Design Expert Software (Version 10.0, Stat - Ease Inc., Minneapolis, MN). Polynomial models including interaction and quadratic terms were generated for all the response variables using multiple linear regression analysis (MLRA) approach. The general form of the MLRA model is represented below:

$$
Y=\beta_{0}+\beta_{1} X_{1}+\beta_{2} X_{2}+\beta_{3} X_{1} X_{2}+\beta_{4} X_{1}^{2}+\beta_{5} X_{2}^{2}+\beta_{6} X_{1} X_{2}^{2}+\beta_{7} X_{1}^{2} X_{2}
$$

Where, $\beta$ o is the intercept representing the arithmetic average of all quantitative outcomes of 10 runs; $\beta_{1}-\beta_{7}$ are the coefficients computed from the observed experimental values of $Y$; and $\mathrm{X}_{1}$ and $\mathrm{X}_{2}$ are the coded levels of the independent variable(s).

The terms $\mathrm{X}_{1} \mathrm{X}_{2}$ and $\mathrm{Xi}_{2}(\mathrm{i}=1-2)$ represent the interaction and quadratic terms, respectively. Statistical validation of the polynomial equation was established on the basis of analysis of variance (ANOVA) provision in the Design Expert Software. Various feasibility and grid searches were conducted to find the composition of optimum formulations. Furthermore, the 3D-response surface graphs and 2D contour plots were constructed using the output files generated [10].

\section{RESULTS AND DISCUSSION}

Drug-excipients compatibility studies using FTIR

In the FTIR study, the various spectra were found as given in Table 3. The $\mathrm{N}-\mathrm{H}$ stretching was found in $1135 / \mathrm{cm}$ in levocetirizine hydrochloride, $3283 / \mathrm{cm}$ in levocetirizine hydrochloride + SSG, 3098.45/cm in

Table 2: Materials used for ambroxol hydrochloride layer

\begin{tabular}{|c|c|c|c|c|c|c|c|c|c|}
\hline $\begin{array}{l}\text { Formulation } \\
\text { no }\end{array}$ & Run & $\begin{array}{l}\text { Ambroxol } \\
\text { hydrochloride } \\
\text { (mg) }\end{array}$ & $\begin{array}{l}\text { SSG } \\
\text { (mg) }\end{array}$ & $\begin{array}{l}\text { Camphor } \\
\text { (mg) }\end{array}$ & $\begin{array}{l}\text { Microcrystalline } \\
\text { cellulose } \\
\text { (mg) }\end{array}$ & $\begin{array}{l}\text { Sodium } \\
\text { saccharine } \\
\text { (mg) }\end{array}$ & Talc (mg) & $\begin{array}{l}\text { Magnesium } \\
\text { stearate (mg) }\end{array}$ & Mannitol (mg) \\
\hline 1 & 1 & 7.5 & 2 & 5 & 2 & 3 & 3 & 5 & 32.5 \\
\hline 2 & 2 & 7.5 & 10 & 5 & 2 & 3 & 3 & 5 & 24.5 \\
\hline 3 & 3 & 7.5 & 2 & 15 & 2 & 3 & 3 & 5 & 22.5 \\
\hline 4 & 4 & 7.5 & 10 & 15 & 2 & 3 & 3 & 5 & 14.5 \\
\hline 5 & 5 & 7.5 & 2 & 7 & 2 & 3 & 3 & 5 & 30.5 \\
\hline 7 & 7 & 7.5 & 3 & 5 & 2 & 3 & 3 & 5 & 31.5 \\
\hline 8 & 8 & 7.5 & 3 & 15 & 2 & 3 & 3 & 5 & 21.5 \\
\hline 9 & 9 & 7.5 & 3 & 7 & 2 & 3 & 3 & 5 & 29.5 \\
\hline
\end{tabular}

SSG: Sodium starch glycolate

Table 3: IR interpretation of the drug and excipients

\begin{tabular}{llllll}
\hline S. no & $\begin{array}{l}\text { Functional } \\
\text { groups }\end{array}$ & $\begin{array}{l}\text { Levocetirizine } \\
\text { hydrochloride } \mathbf{( \mathbf { c m } ^ { - 1 } )}\end{array}$ & $\begin{array}{l}\text { Levocetirizine } \\
\text { hydrochloride+SSG }\end{array}$ & $\begin{array}{l}\text { Ambroxol } \\
\text { hydrochloride }\end{array}$ & $\begin{array}{l}\text { Ambroxol } \\
\text { hydrochloride+crosscarmelosee sodium }\end{array}$ \\
\hline 1 & N-H stretching & 1135 & 3283 & 3098.45 & - \\
2 & C-H stretching & 1433 & 995 (vinyl) & 3025.23 (vinyl) & - \\
3 & C=C stretching & - & 1582 (enolic) & 1486 & 1486 \\
4 & Amides & 1742 & - & $1688(1,4$ quinones) & $1688(1,4$ quinones) \\
5 & C-N vibration & 1317 & - & - & - \\
6 & C-Cl stretching & 756 & 756 & 731.05 & 701.99 \\
\hline
\end{tabular}

SSG: Sodium starch glycolate 
ambroxol hydrochloride. Furthermore, $\mathrm{C}-\mathrm{H}$ stretching was found in $1433 / \mathrm{cm}$ in levocetirizine hydrochloride, $995 / \mathrm{cm}$ in levocetirizine hydrochloride + SSG, 3025/cm in ambroxol hydrochloride and C-Cl stretching was found in $756 / \mathrm{cm}$ in levocetirizine hydrochloride, $731 / \mathrm{cm}$ in ambroxol hydrochloride and $701.99 / \mathrm{cm}$ in ambroxol hydrochloride + croscarmellose sodium. As we study about the structural formula of the drugs, excipients, the following functional groups were seen. Hence, we can conclude that there is no incompatibility found in drug and excipients in the given sample. The FTIR spectra found was given in Fig. 1.

\section{DSC studies}

From the DSC study, the results were found in Fig. 2. The melting point of levocetirizine hydrochloride was found at $220^{\circ} \mathrm{C}\left(215^{\circ} \mathrm{C}\right)$, ambroxol hydrochloride was found at $242^{\circ} \mathrm{C}\left(240^{\circ} \mathrm{C}\right)$, etc., were in the range. Here, we can conclude that there is no type of drug excipients compatibility study found.

Optimization of bilayer sublingual tablets of levocetirizine hydrochloride and ambroxol hydrochloride

\section{Pre-formulation parameters}

The pre-formulation parameters for tablet blend were given in Table 4 .

The results of pre-compression studies reveal that the bulk density of powder blend was found between 0.362 and $0.442 \mathrm{~g} / \mathrm{cm}^{3}$ and tapped density was found between 0.428 and $0.530 \mathrm{~g} / \mathrm{cm}^{3}$ which is in the limit of both bulk density and tapped density. Furthermore, in the case of Carr's index, it was found in between 10 and 11.2 and Hausner's ratio in between
1.06 and 1.99 which holds the assumption of good compressibility. Finally, angle of repose of the powder blend was found in between 25.6 and 31.5 which was having property of good flow of the powder blend.

Post compression parameters of the prepared bilayer sublingual tablets of levocetirizine hydrochloride and ambroxol hydrochloride tablets

The prepared tablets were evaluated for different post-compression parameters such as weight variation, hardness, thickness, friability, and disintegration time and the results are within the limits which depicted in Table 5. This rapid disintegration assists swallowing and also plays a role in drug absorption in buccal cavity, thus promoting bioavailability. Disintegration time of various prepared bilayer tablets of levocetirizine hydrochloride and ambroxol hydrochloride was found to be within the range of 34-130 seconds.

Statistical optimization of bilayer sublingual tablets of levocetirizine hydrochloride and ambroxol hydrochloride tablets ANOVA

ANOVA of the responses indicated that response surface models developed for disintegration time and water absorption was significant and adequate, without significant lack of fit. Influences of formulation variables on the response factors are shown in Table 6.

\section{Model summary statistics}

Model summary statistics for the selected significant models are shown in Table 7 . It can be observed that $R_{2}$ is high for all

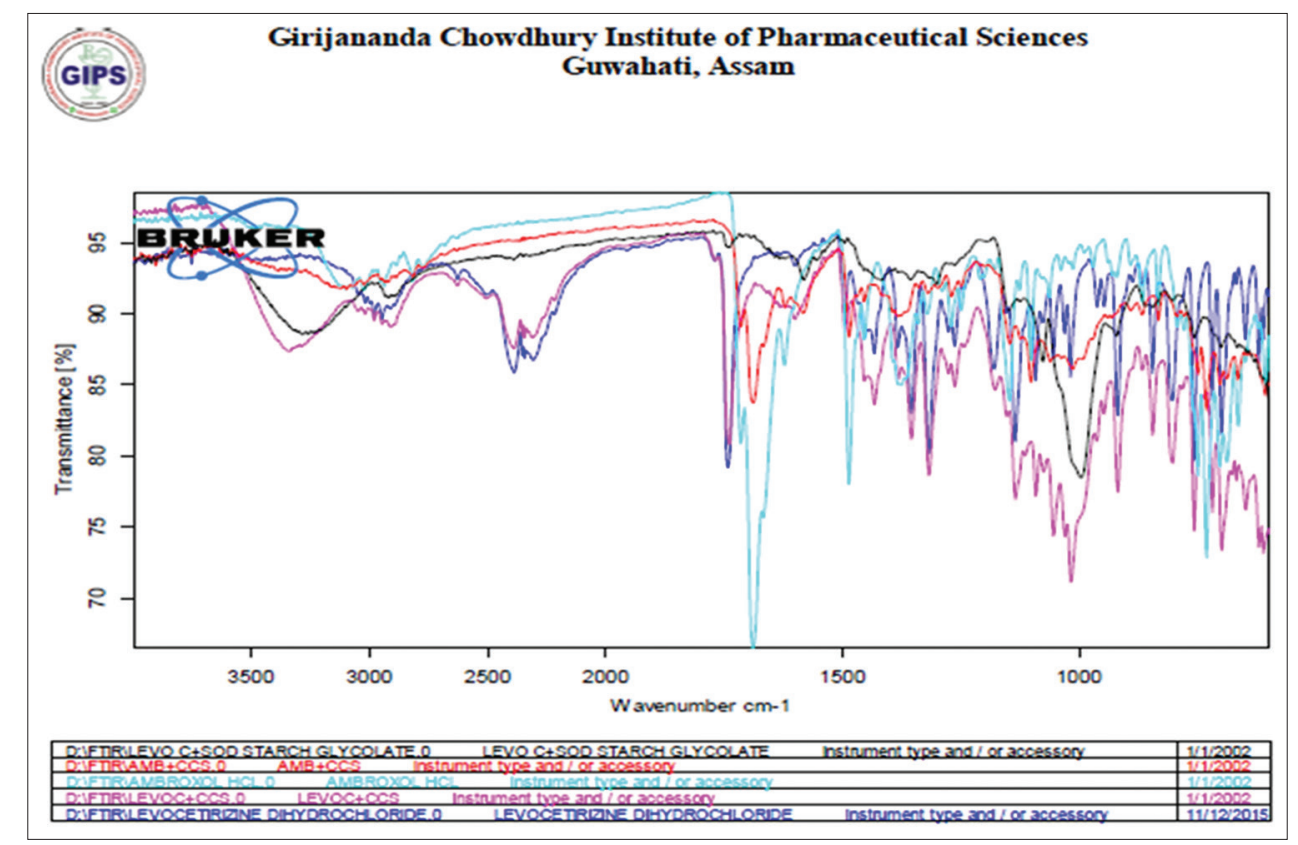

Fig. 1: Fourier transform infrared study of all drug mixture

Table 4: Pre-formulation parameters of the tablet blend

\begin{tabular}{llllll}
\hline Formulation no & Bulk density $(\mathbf{g} / \mathbf{m l})$ & Tapped density $(\mathbf{g} / \mathbf{m l})$ & Carr's index $(\%)$ & Hausner's ratio & Angle of repose $(\boldsymbol{\theta})$ \\
\hline F1 & 0.364 & 0.321 & 10.8 & 1.11 & 31.5 \\
F2 & 0.362 & 0.303 & 10.2 & 1.21 & 30 \\
F3 & 0.379 & 0.311 & 10.2 & 1.13 & 29.6 \\
F4 & 0.375 & 0.322 & 1.57 & 30.2 \\
F5 & 0.360 & 0.409 & 10.8 & 1.06 & 31.5 \\
F6 & 0.419 & 0.410 & 11.1 & 1.20 & 28.6 \\
F7 & 0.417 & 0.414 & 10.0 & 1.07 & 2.1 \\
F8 & 0.416 & 0.428 & & 1.09 & 25.6 \\
F9 & & & & \\
\hline
\end{tabular}




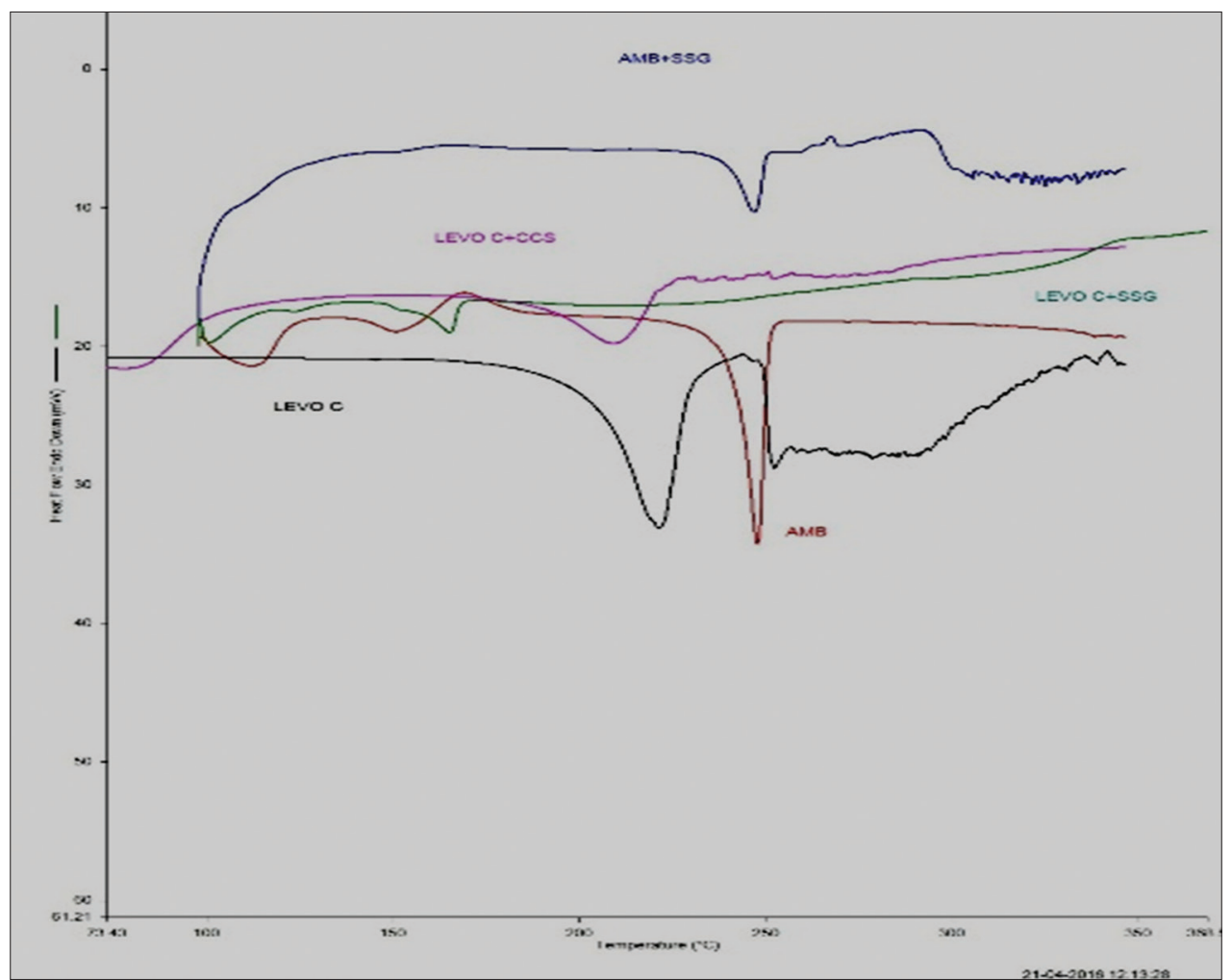

Fig. 2: Differential scanning calorimetry study of all drug mixture

Table 5: Post compression parameters of bilayer sublingual tablets of levocetirizine hydrochloride and ambroxol hydrochloride

\begin{tabular}{|c|c|c|c|c|c|c|c|c|}
\hline $\begin{array}{l}\text { Formulation } \\
\text { no }\end{array}$ & $\begin{array}{l}\text { Thickness } \\
\text { (mm) }\end{array}$ & $\begin{array}{l}\text { Hardness } \\
\left(\mathrm{kg} / \mathrm{cm}^{2}\right)\end{array}$ & $\begin{array}{l}\text { Uniformity } \\
\text { of weight }\end{array}$ & $\begin{array}{l}\text { Friability } \\
(\%)\end{array}$ & $\begin{array}{l}\text { Drug content } \\
(\%)\end{array}$ & $\begin{array}{l}\text { Wetting time } \\
\text { (seconds) }\end{array}$ & $\begin{array}{l}\text { Water Absorption } \\
\text { ratio }\end{array}$ & $\begin{array}{l}\text { In vitro } \\
\text { disintegration } \\
\text { time (seconds) }\end{array}$ \\
\hline $\mathrm{F} 1$ & 3 & 3.5 & $180 \pm 0.37$ & 0.72 & 95.9 & 25 & 44.4 & 34 \\
\hline $\mathrm{F} 2$ & 3 & 3.5 & $180 \pm 0.89$ & 0.68 & 96.8 & 17 & 22.2 & 70 \\
\hline F3 & 3 & 3.5 & $180 \pm 0.23$ & 0.70 & 93.7 & 20 & 58.9 & 110 \\
\hline F4 & 3 & 3.5 & $180 \pm 0.99$ & 0.69 & 97.0 & 21 & 72.2 & 107 \\
\hline F5 & 3 & 3.5 & $180 \pm 0.45$ & 0.81 & 90.9 & 26 & 64.7 & 57 \\
\hline F7 & 3 & 3.5 & $180 \pm 0.56$ & 0.78 & 99.8 & 17 & 50 & 120 \\
\hline F8 & 3 & 3.5 & $180 \pm 0.88$ & 0.61 & 97.8 & 20 & 61.1 & 130 \\
\hline F9 & 3 & 3.5 & $180 \pm 0.90$ & 0.88 & 96.9 & 27 & 56.2 & 110 \\
\hline
\end{tabular}

Table 6: ANOVA-influence of formulation variables on the response factors

\begin{tabular}{lllll}
\hline Response factor & $\begin{array}{l}\text { Model } \\
\text { F-value }\end{array}$ & P>F & $\begin{array}{l}\text { Lack of fit } \\
\text { F-value }\end{array}$ & P>F \\
\hline Disintegration time & 10.80 & 0.0391 & 14.83 & 0.289 \\
X $_{1}$ SSG & 10.56 & 0.0475 & 14.83 & 0.289 \\
X $_{2}$ Camphor & 10.11 & 0.0501 & 14.83 & 0.289 \\
Water absorption ratio & 34.64 & 0.0022 & 0.32 & 0.4866 \\
X $_{1}$ SSG & 165.41 & 0.0002 & 0.32 & 0.4866 \\
X $_{2}$ Camphor & 0.029 & 0.8739 & 0.32 & 0.4866 \\
\hline
\end{tabular}

SSG: Sodium starch glycolate, ANOVA: Analysis of variance

Table 7: Model summary statistics- influence of formulation variables on the response factors

\begin{tabular}{lllll}
\hline Response factor & SD & $\mathbf{R}^{\mathbf{2}}$ & $\begin{array}{l}\text { Adjusted } \\
\mathbf{R}^{\mathbf{2}}\end{array}$ & $\begin{array}{l}\text { Predicted } \\
\mathbf{R}\end{array}$ \\
\hline Disintegration time & 17.46 & 0.9474 & 0.8596 & 0.3668 \\
Water absorption ratio & 7.83 & 0.8157 & 0.7052 & 0.8685 \\
\hline
\end{tabular}

responses, which indicates a high degree of correlation between the experimental and predicted responses. In addition, the predicted $R_{2}$ value is in good agreement with the adjusted $R_{2}$ value, resulting in reliable models.

\section{Mathematical equations}

Mathematical relationships generated using multiple regression analysis for the studied response variables are expressed as equations (I and II). The equation in terms of actual factors can be used to make predictions about the response for given levels of each factor.

Disintegration time $=113.67-23.17 \mathrm{X}_{1}+22.67 \mathrm{X}_{2}$

$$
\begin{aligned}
& -16.75 X_{1} X_{2}-5250.27 X_{1}^{2}+42.00 X_{2}^{2} \\
& -973.14 X_{1} X_{2}^{2}+1190.17 X_{1}^{2} X_{2}
\end{aligned}
$$

Water absorption ratio $=53.67-3.35 \mathrm{X}_{1}+12.67 \mathrm{X}_{2}$

$$
\begin{aligned}
& -42.44 X_{1} X_{2}+11.22 X_{1}^{2}+160.52 X_{2}^{2} \\
& -537.74 X_{1} X_{2}^{2}+142.157 X_{1}^{2} X_{2}
\end{aligned}
$$




\section{Response surface analysis}

The 3D-response surface plots are shown in Fig. 3 and the corresponding contour plots for the studied response properties, viz., disintegration time and water absorption ratio are shown in Fig. 3.

\section{Effect of variable in disintegration time}

The variables on the present study, i.e., the amount of SSG and camphor had equal effects in both the responses. These variables effect equally on the disintegration time (seconds) as can be seen in the contour (Fig. 3) as well as 3D-surface plot (Fig. 4).

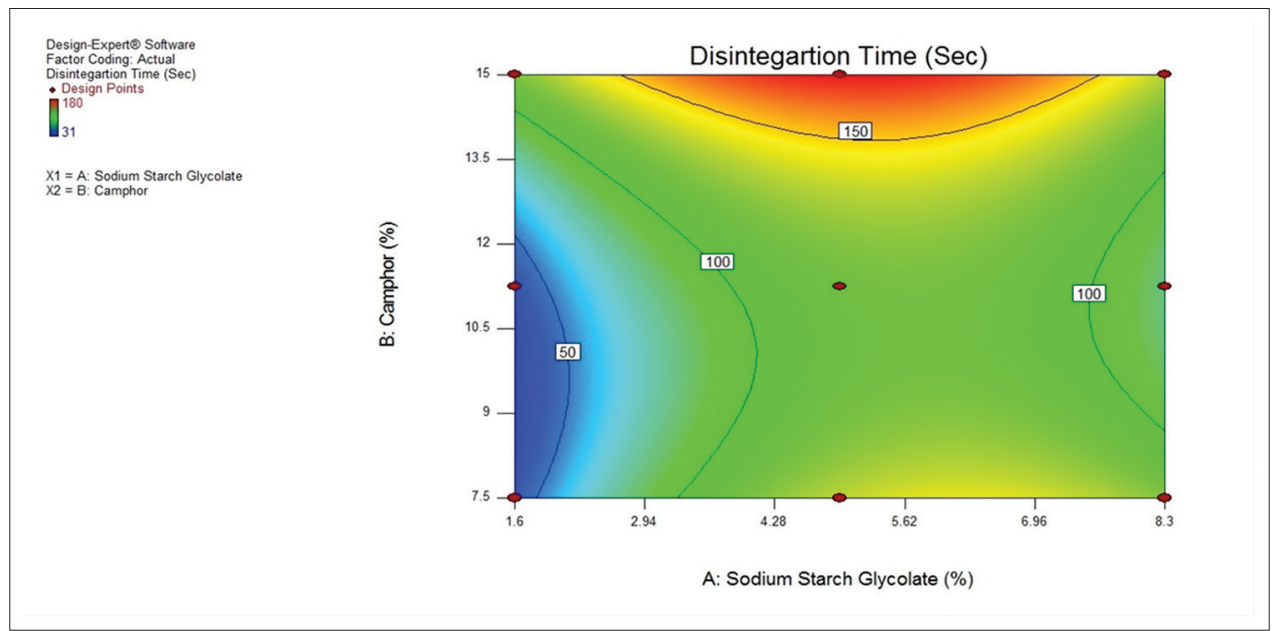

Fig. 3: Contour plot showing the relationship between various levels of two factors on disintegration time

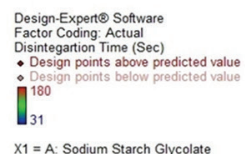

$x_{1}=A:$ : Solium Starch Glycolate
$x_{2}=\mathrm{B}:$ Camphor

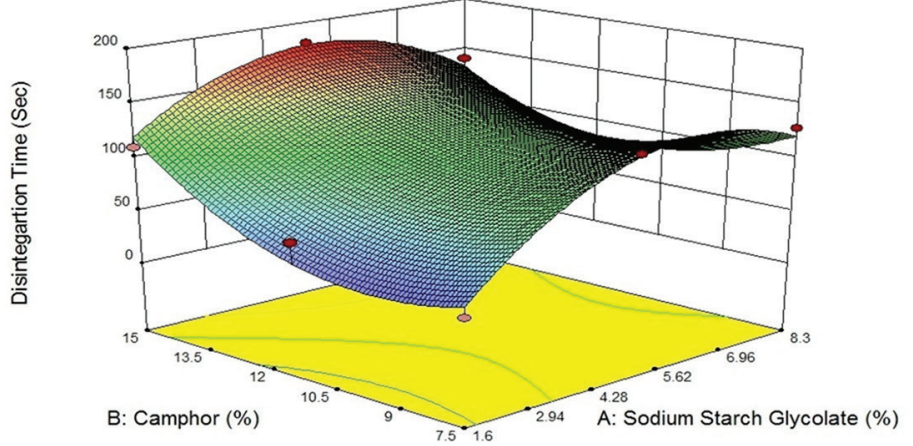

Fig. 4: Three-dimensional-response surface plots showing the influence of two different factors on disintegration time

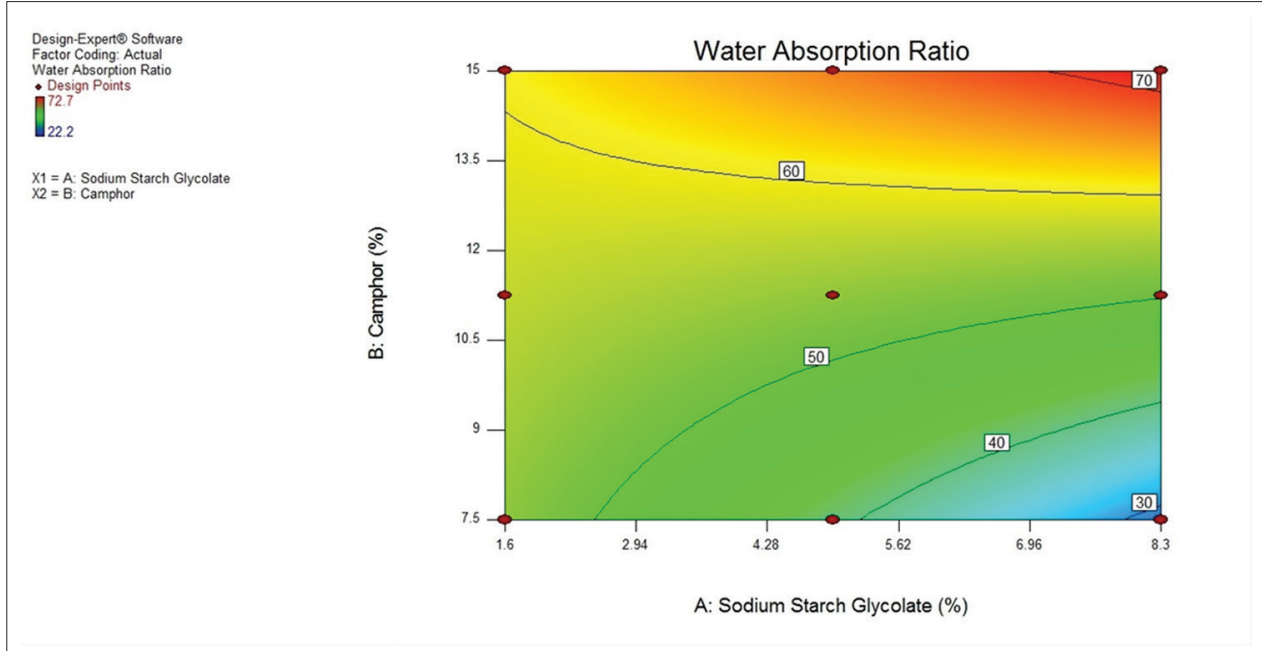

Fig. 5: Contour plot showing the relationship between various levels of two factors on water absorption ratio 


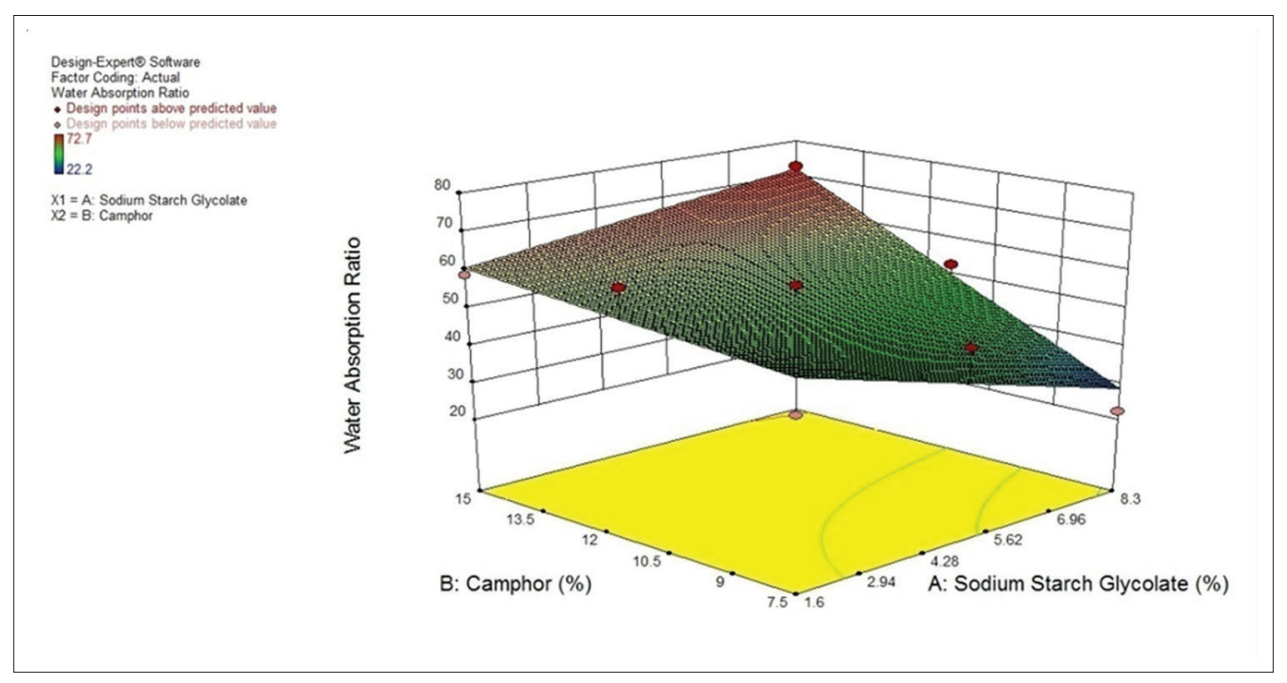

Fig. 6: Three-dimensional-response surface plot showing the influence of two factors on water absorption ratio

Table 8: Composition of the optimized formulation, the predicted and experimental values of response variables, and percentage prediction error

\begin{tabular}{lllll}
\hline Composition SSG:Camphor & Responses variable & Experimental value & Predicted value & Percentage error \\
\hline $4.95: 15$ & Disintegration time (seconds) & 61 & 45.28 & 3.47 \\
& Water absorption ratio & 69.67 & 91.21 & 2.36 \\
\hline
\end{tabular}

SSG: Sodium starch glycolate

\section{Effect of variables in water absorption ratio}

The variables on the present study, i.e., the amount of SSG and camphor had equal effects in both the responses. These variables effect equally on the water absorption ratio as can be seen in the contour (Fig. 5) as well as 3D-surface plot (Fig. 6).

\section{Validation of results}

To evaluate the optimization capability of the models generated according to the results of the central composite design, tablets including the optimized formulation were prepared using the optimal process variable settings. All results of the physical evaluation were found to be within limits. Table 8 lists the composition of the final batch, its predicted and experimental values of all the response variables, and the percentage error. From the Table 8, it was cleared that the percentage errors for optimized batch with response variable disintegration time was found to be 3.47 and that of water absorption ratio was found to be 2.36 .

\section{CONCLUSION}

The response surface methodology using central composite design (Design Expert Software, Version 10.0. Stat - Ease Inc., Minneapolis, MN) with 2-factor, 3-level central composite design with super disintegrants SSG and camphor was employed for optimization of bilayer sublingual tablets of levocetirizine hydrochloride and ambroxol hydrochloride. The quantitative effects of the factors at different levels on the responses could be predicted using polynomial equations. The observed responses were found to be in close agreement with the predicted values for optimized formulations. The direct compression method in this study is relatively simple and safe and a stable, effective and pleasant tasting fast dissolving tablets, which has a good balance over disintegration time and water absorption ratio, was formulated.

\section{ACKNOWLEDGMENTS}

First and foremost, I'd like to thank my Principal Dr. Suvakanta Dash for giving me an opportunity to do the research work. Also obviously I also pay my sincere gratitude to my guide, assistant professor Dr. Pulak Deb for his guidance, supervision and helping me throughout this research work. The authors are thankful to Balaji Suppliers, for providing with levocetirizine hydrochloride and ambroxol hydrochloride. The authors also wish to thankful to Girijananda Chowdhury Institute of Pharmaceutical Science for providing the necessary facilities for carrying out the research work.

\section{REFERENCES}

1. Vishwakarma AG, Mogal RT, Pawar AY. Bi-layer tablet - A new ways in oral drug delivery system. Int J PharmTech Res 2014;6(5):1416-28.

2. Gandhi GS, Mundhada DR, Bhaskaran S. Levocetrizine orodispersible tablet by direct compression method. J Appl Pharm Sci 2011;01(05):145-50.

3. Ramana G, Sravanthi O, Sahithi G, Sindhu NV. Formulation and evaluation of controlled release hydrophilic matrices of ambroxol hydrochloride by melt granulation technique. AEJR 2012;7(4):150-9.

4. Sahoo BK, Mishra AK, Pal TK. Optimization and validation of modulated release formulation of ranitidine hydrochloride by response surface methodology. IJPSDR 2011;3(1):13-8.

5. Dekivadia M, Gudigennavar M, Patil C, Umarji B. Development \& optimization of fast dissolving tablet of levocetrizine hydrochloride. Int J Drug Dev Res 2012;4(2):237-46.

6. Rane DR, Gulve HN, Patil VV, Thakare VM, Patil VR. Formulation and evaluation of fast dissolving tablet of albendazole. Int Curr Pharm J 2012;1(10):311-6

7. Arunprashad B, Teja GK. Design and evaluation of bilayer tablets to treat respiratory tract infection. Int J Pharm Pharm Sci 2013;5(1):250-5.

8. Anjankumar PB, Nazmuddin M, Kulkarni U, Hariprasanna RC. Formulation and evaluation of lornoxicam fast dissolving tablet. Int Res J Pharm 2011;2(4):130-40.

9. Mohire NC, Yadav AV. Novel approach to formulate B-cyclodextrin complexed mouth dissolving tablet of metronidazole and its in-vitro evaluation. J Pharm Res 2010;3(3):662-700.

10. Mishra RA. Optimization and characterization of rapidly dissolving films of cetirizine hydrochloride using cyclodextrins for taste masking. IJPRIF 2013;5(2):536-52. 